\title{
Reaktualisasi Dharma Dakwah Islamiyah Kampus UII Demangan Baru ${ }^{1}$
}

\author{
Ahmad Darmaji, Syarief Zudaidah, Yusdani \\ dan Edi Safitri \\ Fakultas Ilmu Agama Islam (FIAI), Universitas Islam Indonesia, \\ Jl. Demangan Baru 24, Yogyakarta. \\ Email:yusdani_msi@yahoo.com
}

\begin{abstract}
The following research tries to answer the research question of how the portrait and the dynamics of society around campus of UII Jalan Demangan Baru No. 24

Yogyakarta? And how social dynamics of society from the perspective of Islamiyah Dakwah as one of the dharma UII? This research is a field and qualitative research, the location of research at Campus UII Jalan Damangan Baru No. 24

Yogyakarta. The approach that used in this study is phenomenological approach. The analysis which used in this study is the analysis of Miles that including: data reduction, data display and conclusion drawing / verification as an intertwined at the time before, during, and after the collection of data in parallel, to build conclusion. The results of this research has been revealed that the religious community in Campus UII Jalan Demangan Baru emphasizes tolerance. However, the attitude of this potential, by the Campus Ull has never seen as an opportunity to do various efforts to strengthen through service programs and Islamiyah Dakwah. In addition to this research also found that the relationship between the Campus UII Jalan Demangan Baru with itys several units and the local community, not shown
\end{abstract}

as partners of both planned and programmed for mutual support and cooperation between two entites.

Keywords: dakwah, Universitas Islam Indonesia, religious life, lembaga pendidikan Islam.

\section{ABSTRAK}

Penelitian ini membahas persoalan bagaimana potret dan dinamika kehidupan keberagamaan masyarakat di sekitar kampus UII Jalan Demangan baru No. 24 Yogyakarta? Dan bagaimana dinamika keberagamaan masyarakat tersebut dilihat dalam perspektif dakwah Islamiyah sebagai salah satu catur dharma UII? Penelitian ini adalah penelitian lapangan (kualitatif), lokasi penelitiannya di Kampus UII Jalan Demangan Baru No. 24 Yogyakarta. Pendekatan yang dipakai dalam penelitian ini adalah fenomenologis. Analisis yang dipergunakan dalam penelitian ini adalah analisis Miles yaitu: reduksi data, penyajian data, dan penarikan kesimpulan/verifikasi sebagai suatu yang jalin-menjalin pada saat sebelum, selama, dan sesudah pengumpulan data dalam bentuk yang sejajar, untuk membangun kseimpulan. Hasil penelitian ini menunjukkan bahwa keberagamaan masyarakat di lingkungan Kampus UII Demangan Baru lebih mengedepankan sikap toleransi. Akan tetapi sikap potensi ini, oleh pihak Kampus tidak pernah dilihat sebagai peluang untuk dilakukan berbagai upaya penguatan melalui program pengabdian dan dakwah Islamiyah. Selain itu dalam penelitian ini pula dapat ditemukan bahwa relasi antara pihak kampus UII Demangan Baru dengan berbagai unitnya dan masyarakat di lingkungannya, belum menunjukkan sebagai partner kerjasama terencana dan terprogram secara baik untuk saling mendukung dan bekerjasama antara keduanya.

Kata kunci: dakwah, Universitas Islam Indonesia, kehidupan keagamaan, institusi pendidikan Islam. 


\section{PENDAHULUAN}

Keberadaan Perguruan Tinggi Islam secara Institusional memainkan peranannya sebagai mitra masyarakat sekitarnya. Salah satu misi Perguruan Tinggi Islam sebagai institusi pendidikan tinggi melekat tanggung jawab moral melakukan dakwah Islamiyah, yaitu berbagai upaya mengarahkan dan mengubah masyarakat ke arah yang lebih baik. Dengan begitu, Universitas sebagai pusat pengembangan ilmu pengetahuan, kultur dan kebudayaan beserta civitas akademiknya, tidak bisa lagi diposisikan sebagai "ivory tower" atau menara gading (https:// www.google.co.id). Universitas Islam Indonesia (selanjutnya disebut UII) membangun komitmen yang khas jika dibandingkan dengan perguruan tinggi lainnya. Jika perguruan tinggi lain secara umum berpijak pada Tridharma Perguruan Tinggi, Pengajaran, Penelitian dan Pengabdian Masyarakat. Sedangkan bagi UII dicanangkan dharma keempat, yaitu dakwah Islamiyah.

Salah satu kampus UII yang mempunyai posisi strategis yang dapat melakukan upaya di atas adalah kampus UII Jalan Demangan Baru No. 24 Yogyakarta. Pilihan terhadap kampus UII Demangan Baru sebagai subjek riset ini karena pertama, keberadaan kampus ini yang sudah lama yaitu sejak tahun 1973. Kampus Demangan merupakan gedung kampus kedua yang dimiliki UII setelah gedung kampus Cik Ditiro. Kedua, posisi gedungnya yang strategis. Keberadaan kampus ini berada di tengah kota dan diapit oleh 3 kampus besar (UIN Sunan Kalijaga, Sanata Darma, dan Atmajaya) serta pusatpusat perbelanjaan serta berbagai hotel dan wisma. Ketiga, masyarakatnya begitu plural dan hidup berdampingan secara rukun. Keempat, visi UII mewujudkan rahmatan lil'alamin dan jargon berilmu amaliyah dan beramal ilmiah serta pencanangan Dharma keempat yang mengedepankan dakwah Islamiyah sebagai unsur dominan dalam mengkristalkan misi Universitas Islam Indonesia.

Berdasarkan visi UII di atas dan catur dharmanya, maka idealnya keberadaan kampus beserta segenap civitas akademiknya mampu mewarnai masyarakat sekitar. Selain itu, bertitik-tolak dari beberapa tulisan dan hasil penelitian tentang UII secara umum dan khususnya kampus UII masih terbatasnya basis data atau informasi dan pembahasan tentang eksistensi dan peran kampus UII di Jl. Demangan Baru No. 24. Pada hal kampus UII Demangan ini secara historis lebih dahulu berdiri juga, letaknya strategis karena terletak di perkotaan dan masyarakat sekitar kampus ini dapat dikategorikan sebagai masyarakat awam dan terdidik. Atas dasar itu, penelitian ini urgen dilakukan terutama dalam kerangka dan konteks dakwah Islam sebagai aktualiasasi visi rahmatan lil lamin UII dalam kehidupan keberagamaan masyarakat.

Persoalan pokok yang menjadi fokus dalam penelitian ini adalah bagaimana potret dan dinamika kehidupan keberagamaan masyarakat di sekitar kampus UII Jalan Demangan baru No. 24 Yogyakarta? dan bagaimana dinamika keberagamaan masyarakat tersebut dilihat dalam perspektif dakwah Islamiyah sebagai salah satu catur dharma UII? Kontribusi penting penelitian ini diharapkan dapat memperkaya basis data peta keberagamaan masyarakat yang berada di sekitar kampus-kampus UII. Dengan begitu, dapat pula dipahami dinamika dan karaketristik keberagamaan masyarakat di sekitar kampus UII Demangan Baru, yang selanjutnya akan dapat digunakan sebagai 
basis data untuk mengimplementasikan dakwah islamiyah sebagai dharma keempat dari catur dharma UII.

\section{TENTANG TRI DHARMA UII}

Potret perkembangan PTAI sekarang ini, saatnya perlu dipikirkan kembali, terutama kegiatan pengabdian masyarakat seharusnya dilakukan sebagai tindak lanjut dari rekomendasi penelitian. Begitu juga sebaliknya, agar topik-topik penelitian dirumuskan dari temuan dalam pengabdian masyarakat. Dengan demikian, keseimbangan dan kesetaraan tiga dharma dari Tri Dharma (baca khusus bagi UII menganut catur dharma, dakwah Islam) Perguruan Tinggi penting dilakukan dalam setiap program akademik.

Peran dakwah perguruan tinggi Islam ke masyarakat perlu lebih dikembangkan karena selama ini dinilai kurang maksimal. Oleh karena itu, perguruan tinggi Islam seharusnya bukan semata-mata melakukan peran pengembangan ilmu pengetahuan, teknologi dan seni, melainkan juga melakukan dakwah dalam arti luas bukan dalam arti tablig, yaitu mengembangkan kehidupan masyarakat secara luas. Namun, dakwah perguruan tinggi Islam terasa kering baik dari sisi model maupun terapannya sehingga kurang begitu dirasakan manfaatnya oleh masyarakat. Dengan begitu, tri dharma ( catur dharma dalam kasus UII) perguruan tinggi Islam harus didesain sedemikian rupa unutk mempengaruhi suasana kehidupan masyarakat. Seluruh kehidupan perguruan tinggi Islam, harus menjadi contoh teladan bagi kehidupan masyarakat agar nuansa kehidupan Islam dapat dirasakan dengan jelas ( (http://fahum.umsu.ac.id/ index.php?option accessed 15 Juli 2014).
Berangkat dari pernyataan di atas, UII sebagai institusi pendidikan tinggi dengan catur dharmanya, dalam kaitannya dengan transformasi nilai-nilai peradaban masyarakat yang berada di sekitar kampus, kampus UII memiliki peran dan fungsi yang penting dalam mewarnai terjadinya perubahan nilainilai sosial budaya serta pengembangan peradaban masyarakat, baik dari aspek ekonomi, sosial, politik, keagamaaan maupun pendidikan. Dengan begitu, orientasi untuk mewujudkan UII dengan mengedepankan aktivitas akademis dan moral serta relevansinya dengan menerapkan peran aktif UII sebagai institusi yang mengaplikasikan pola pemberdayaan dan pengembangan masyarakat, khususnya yang berada di sekitar kampus.

Oleh karena itu, keberadaan kampus UII di tengah-tengah masyarakat seharusnya dapat memberikan nuansa baru bagi kehidupan mereka, terutama dalam bidang kehidupan agama, ekonomi, sosial, budaya dan lain sebagainya. Dampak dari kondisi ini adalah terjadinya pembaruan yang memungkinkan adanya perubahan tatanan sosial kehidupan masyarakat sekitar kampus. Dampak perubahan yang ditimbulkan oleh akulturasi budaya tersebut, dapat bersifat positif dan juga negatif. Perubahan positif bentuknyapun bervariasi, baik dari aspek ekonomi yang ditandai oleh peningkatan penghasilan masyarakat setempat, maupun kualitas pengetahuan dan wawasan masyarakat semakin membaik, serta perkembangan budaya yang lebih dinamis. Dengan demikian, visi UII yang menekankan pada aspek kerahmatan dalam pelaksanaan sebagai institusi pendidikan Islam, akan tidak banyak arti jika secara implementatif justru kurang mewarnai 
lingkungan sekitarnya.

Suatu interaksi sosial kampus UII akan terjadi apabila memenuhi dua syarat, yaitu: adanya kontak sosial dan adanya komunikasi. Selain interaksi yang terjalin pada masyarakat di kawasan kampus dipenuhi oleh dua hal ini, baik kontak sosial maupun komunikasi.

Dalam hbungan inilah dapat dipahami bahwa pola relasi dunia kampus perguruan tinggi perlu membangun kemitraan dengan masyarakat sekitar.

Sedangkan untuk menjelaskan bagaimana dakwah Islam yang seharusnya dilakukan oleh civitas akademika UII dengan lingkungan masyarakat sekitarnya merupakan usaha untuk mempertautkan Islam dengan isu-isu kemanusiaan masyarakat di lingkungannya, dapat dipergunakan konsep yang ditawarkan oleh Kuntowijoyo, yaitu internalisasi, obyektivikasi, dan eksternalisasi. Pertama, pemahaman akan pesan-pesan universal Islam untuk diinternalisasikan ( dihayati) oleh civitas akademika UII. Tahapan internalisasi tidak bisa dilakukan tanpa kerja keras dan cerdas. Semangat pencarian yang tinggi menjadi syarat utama. Internalisasi adalah proses pencarian hidayah atau reinventing pesanpesan Islam.

Kedua, obyektivikasi dilakukan untuk melihat konteks implementasi. Sadar konteks merupakan keharusan untuk mendapatkan hasil yang optimal dari dakwah Islam sebagai dharma keempat UII. Tanpa kesadaran ini, ada kemungkinan program atau aktivitas dakwah Islam yang dicanangkan menjadi tidak kontekstual. Kuntowijoyo memasukkan obyektivikasi sebagai bagian dari strategi aktualiasasi Islam dalam masyarakat. Dalam konteks pembumian Islam oleh UII unutk kehoiudpan masyarakat di lingkungannya, obyektivikasi dapat dilakukan dengan melihat potret utuh kehidupan masyarakat dalam berbagai sisinya. Ketiga, eksternalisasi adalah implementasi dari nilai-nilai yang telah terinternalisasi ke dalam konteks yang ada. Tanpa ekternalisasi, visi rahmatal lil'alamin yang tertuang dalam visi UII tidak akan terwujud dan hanya berhenti dalam wacana.

\section{METODE PENELITIAN}

Penelitian ini merupakan penelitian lapangan (kualitatif), lokasi penelitiannya di Kampus UII Jalan Demangan Baru No. 24 Yogyakarta. Pendekatan yang dipakai dalam penelitian ini adalah fenomenologis. Pendekatan fenomenologis dipergunakan untuk memahami kecenderungan dan fenomena Islam yang dipahami dan ditransformasikan yang diterjemahkan dalam berbagai aktivitas (dakwah ) oleh masingmasing unit di Kampus UII Demangan dan respon masyarakat sekitar kampus tersebut atas berbagai aktivitas masing-masing unit tersebut.

Teknik pengumpulan data yang dipergunakan dalam penelitian ini menggunakan dokumen dan wawancara. Wawancara ditujukan kepada masing-masing unit dan masyarakat sekitar terkait dengan Islam yang dipahami dan ditransformasikan yang diterjemahkan dalam berbagai aktivitas (dakwah). Analisis penelitian ini terdapat tiga hal utama yang menurut Miles untuk menganalisis data yaitu: reduksi data, penyajian data, dan penarikan kesimpulan/ verifikasi sebagai suatu yang jalin-menjalin pada saat sebelum, selama, dan sesudah pengumpulan data dalam bentuk yang sejajar, untuk membangun wawasan umum yang disebut analisis. 


\section{HASIL PENELITIAN DAN PEMBAHASAN}

Berdasarkan temuan di lapangan menunjukkan bahwa fenomena keberagamaan masyarakat Kampung Demangan Baru Dusun Papringan lebih mengedepankan toleransi dengan mengedepankan persamaan dan kerukunan. Hal ini bisa dicermati dari keterlibatan mereka dalam berbagai kegiatan yang diselenggarakan oleh kampung. Gotong royong misalnya, baik yang beragama Islam, Katholik, Kristen semua turun dan bekerja bersama-sama untuk kepentingan bersama dalam kehidupan bermasyarakat (lihat hasil wawancara, 15 Oktober 2014).

Hal menarik dari prilaku keberagamaan masyarakat Demangan Baru bahwa gesekan pemahaman demikian sudah tidak terjadi lagi sejak lama. Masih menurutnya, Jangankan internal agama (masih sama-sama Islam), bahkan masyarakat sudah mampu rukun terhadap warga lainnya yang berbeda keyakinan. Misalnya saja, setiap ada hajatan di rumah warga yang beragama Islam, katakanlah selamatan (kenduren) untuk orang yang meninggal dunia, semua warga diundang tanpa mempersoalkan perbedaan agama (lihat hasil wawancara, 16 Oktober 2014).

Berdasarkan temuan dan penjelasan di atas dapat pula dipahami bahwa bagi masyarakat di lingkungan Kampus UII Demangan Baru, agama sebagai persoalan individu dan menempatkan kerukunan antar warga di atas segalanya tanpa mengurangi nilai keyakinan masing-masing pemeluknya di masyarakat Demangan Baru Papringan ini juga dapat dilihat dalam acara-acara doa bersama. Sebagaimana diungkapkan dari hasil wawancara dengan Drs. Ibnu Hajar, SH, MIS ketua RW dan sekaligus tokoh masyarakat Paringan menjelaskan bahwa di Papringan pernah juga melakukan doa bersama lintas agama. Hal itu tidaklah menjadi permasalahan keagamaan di masyarakat. Akan tetapi jika menyangkut isu kristenisasi ada sebagian masyarakat yang menunjukkan kekhawatirannya untuk tidak menyebut kecurigaan terhadap aktifitas kristenisasi ini. Bahkan ketika datang hari besar keagamaan lebaran dan hari Natal, hampir seluruh warga yang beragama Islam maupun Nasrani saling mengucapkan selamat. (lihat wawancara, 16 Oktober 2014).

Gedung Kampus UII Demangan Baru berdiri pada tahun 1973. Keberadaan kampus tersebut merupakan kampus kedua yang dimiliki UII setelah gedung kampus yang berada di Cik Ditiro. Sejak berdirinya, gedung tersebut ditempati oleh Fakultas Teknik Sipil (FTS UII). FTS menempati gedung tersebut untuk aktivitas perkuliahan hingga tahun 1994. Setelah FTS sudah memiliki gedung sendiri, Tahun 1994 FTS hijrah ke kampus terpadu UII yang berada di jalan Kaliurang. Selanjutnya Kampus Demangan berganti penghuni dan giliran ditempati untuk kegiatan perkuliahan Fakultas Syariah dan Fakultas Tarbiyah yang pada perkembangan selanjutnya kedua fakultas tersebut digabung menjadi Fakultas Ilmu Agama Islam Ilmu Agama Islam (FIAI UII) hingga sekarang.

Seiring berjalannya waktu, kampus Demangan Baru tidak hanya digunakan untuk kegiatan perkuliahan mahasiswa S1 saja, tahun 1997, Magester Studi Islam (MSI UII sekarang PPS FIAI UII) berdiri dan juga menempati gedung yang sama untuk aktifitas perkuliahan. Sampai akhirnya beberapa pusat studi dan unit-unit usaha juga mengambil tempat oprasinya di gedung 
Demangan Baru ini. Sebut saja Pusat Studi Islam UII (PSI UII), CILAC UII, Pusat Bahasa Korea, Radio Unisi, Pusat Studi HAKI.

Bangunan Kampus Demangan Baru sampai kini masih terus digunakan sebagai tempat perkuliahan atau beraktifitas lainnya. Meskipun para penghuni datang dan pergi silih berganti. Sejak tahun 2004, FIAI hijrah dan melakukan aktifitas perkuliahannnya di Kampus terpadu (Kampus UII Jl. Kaliurang). Dan pada tahun-tahun berikutnya beberapa pusat studi dan unit usaha yang menempati gedung ini juga pindah dengan berbagai alasan dan pertimbangan. Pada akhirnya lembaga-lembaga yang hingga kini masih bertahan menempati gedung Kampus UII Demangan Baru adalah PPS FIAI UII, Pusat Studi Islam UII, CILAC UII, Radio UNISI, RPI dan Pusat Psikologi Terapan Fakultas Psikologi dan Budaya UII.

Dinamika UII, sebagaimana dijelaskan bahwa terdapat beberapa hal yang bisa dijadikan raison d'etre ( latar belakang dan dasar pijak) kemunculan UII di tengah perjuangan bangsa Indonesia untuk mencapai kemerdekaan. Pertama, UII hadir bukan hanya berorientasi mengemban misi menyelenggarakan proses pendidikan, tetapi juga ingin melakukan pembelajaran terhadap masyarakat dan bangsanya pada tingkat perguruan tinggi. Kedua, momentum perjuangan bangsa untuk melakukan restrukturisasi politik setelah bertahun-tahun berada di bawah kekuasaan asing, telah melahirkan dan menumbuhkan kesadaran arti penting pendidikan. Ketiga, UII ingin mencoba melakukan sosialisasi ajaran agama Islam melalui perguruan tinggi.

Berdasarkan paparan di atas, terlihat UII pada level institusi, sedang bersungguhsungguh menempatkan diri pada posisi agar keberadaan dan kehadirannya, benar-benar memberikan kebaikan bagi masyarakat secara luas. Sehingga dalam dinamikanya UII tidak hanya berkutat pada mengkaji pengembangan universitas dengan segala aktivitas akademiknya, melainkan juga turut pula berupaya untuk terlibat dan berkontribusi menyelesaikan berbagai persoalan masyarakat yang diwujudkan baik melalui program-program universitas, fakultas-fakultas, lembaga-lembaga yang ada di lingkungan universitas, maupun melalui pengembangan program studi yang merespon kebutuhan umat.

Hal tersebut semakin diperkuat jika mengacu pada perumusan tujuan UII yang termaktub dalam Kaidah Dasar dan Statuta UII. Disebutkan setidaknya ada dua hal terkait penyelenggraan UII sebagai perguruan tinggi Islam. Pertama, Basic Philosophy, pengembangan ilmunya adalah integralistik, tidak dikotomis antara ilmu agama dan ilmu umum. Kedua, prilaku sivitas akademikanya haruslah islami, artinya harus mampu menunjukkan keagungannya dan kedamaian Islam sebagai agama, yang paling baik dan tidak ada yang mengatasi kebaikannya. Pernyataan kedua hal inilah yang dijadikan sebagai dasar penyelenggraan aktivita di UII. Atau dengan istilah lain disebut dengan istilah ruhul Islam. Ini berarti bahwa setiap kegiatan belajar mengajar dan pola hubungan antar sivitas akademika di UII harus didasarkan pada spirit Islam yang mestinya bisa tercermin pula pada tingkah laku profesionalnya.

Apa yang secara normatif terumuskan dalam Kaidah Dasar dan Statuta UII, tentulah sesuatu yang sangat Ideal. Desain akademik UII secara eksplisit mengintegrasikan dunia kampus dengan 
masyarakat sesuai jargonnya " berilmu amaliah dan beramal ilmiah”. Hal ini secara eksplisit juga tercermin dalam RIPPM UII 2014-2018 tepatnya dalam rumusan Tujuan UII poin 4 yang berbunyi bahwa "Tujuan UII adalah mendalami, mengembangkan dan menyebarluaskan pemahaman ajaran agama Islam untuk dihayati dan diamalkan oleh warga UII dan masyarakat”. Oleh karenanya untuk mewujudkan hal tersebut, UII secara institusi menganut dan menjalankan apa yang disebut Catur Dharma dalam berbagai jenis dan jenjang pendidikan. Catur Dharma yang dimaksud meliputi "pengajaran, penelitian, pengabdian masyarakat dan dakwah islamiyah" (Statuta UII, pasal 1 ayat 6).

Memang seharusnya relasi seperti tersebut di atas yang terbangun antara perguruan tinggi dan masyarakat. Kampus tidak bisa lagi mendudukkan diri mereka di atas "ivory tower" atau menara gading. Keberadaan Perguruan Tinggi Islam secara institusional memainkan peranannya sebagai kekuatan dakwah. Meskipun misi Perguruan Tinggi Islam yang utama adalah sebagai lembaga akademik, namun pada level institusi pendidikan yang menyandang nama Islam tentu melekat pula tanggung jawab moral melakukan berbagai upaya mengarahkan dan mengubah masyarakat ke arah yang lebih baik lewat peran-perannya.

Dinamika keberagamaan masyarakat sekitar Kampus Demangan Baru dilihat dalam konteks dan perspektif dakwah islamiyah dalam statuta UII sebagai Dharma ke empat. Dalam hal ini menarik mengutip pernyataan Ibu Sunarti (wawancara, 10 Oktober 2014), warga Demangan Baru yang sehari-hari berjualan di sekitar Kampus UII Demangan Baru, menurutnya selama ini tidak pernah ada undangan atau kegiatan apapun dari pihak kampus. Baik itu dari fakultasnya (FIAI UII) mahasiswanya maupun dari unit-unit usaha yang berada di Kampus UII Demangan Baru. Ditambahkan pula bahwa pada tahun 2007 pernah diajak pelatihan ekonomi namun yang mengundang bukan Kampus Demangan Baru melainkan Lembaga Swadaya Masyarakat (LSM-NGO) Satu Nama.

Tentang ketiadaan kegiatan Kampus UII Demangan Baru yang melibatkan masyarakat sekitar juga dikemukakan oleh bapak Sarwono pemilik warung makan yang berada tepat di depan Kampus UII Demangan. Menurut Sarwono (wawancara 10 Oktober 2014), selama dia menjajakan dagangannya di depan kampus, tidak pernah dilibatkan dalam setiap kegiatan termasuk kegiatan keagamaan seperti pengajian. Keberadaan kampus Demangan terhadap usaha kami dan mungkin juga yang lainnya, mungkin sebatas menambah laris. Karena banyak karyawan ataupun mahasiswa yang makan di warung saya. Itupun dulu saat FIAI masih di Kampus UII Demangan Baru tetapi sekarang ketika fakultas agama itu sudah pindah, yang membeli makan disini hanya satu dua dari karyawan maupun staf di situ.

Informasi senada juga datang dari bapak Heri ( lihat hasil wawancara, 10 Oktober 2014), warga Demangan Baru No. 29 yang sehari-hari usaha foto copy dan kebutuhan alat tulis (ATK). Menurutnya meskipun keberadaan kampus sama sekali tidak pernah melibatkannya dalam kegiatan setidaknya ada manfaatnya. Hal ini karena sebagian warga kampus belanja ke tokonya seperti halnya warga kampus Atmajaya maupun Sanata Dharma. Apa yang diungkapkan masyarakat tersebut memperoleh pembenaran dari Nur 
Hamid (wawancara, 15 Oktober 2014) Kepala

Dukuh Papringan. Bahkan ditambahkan

bahwa justru yang sering menyapa masyarakat sekitar Kampus UII Demangan

sepeti SMA Debrito, yang secara administrasi kependudukan juga masuk wilayah

Papringan. Setiap ada kegiatan sering mengundang warga atau bahkan beberapa kali mengajak kami kerja sama. Selain itu UIN pada masa kepemimpinan Amien Abdullah juga sering mengundang warga sekitar. UGM pun kabarnya sering melibatkan mahasiwa untuk bakti sosial di masyarakat sekitar kampus.

Akan tetapi ketika FIAI masih menempati gedung Kampus UII Demangan Baru, sebagian mahasiswa yang indekos di sekitar kampus juga turut berperan dalam kegiatan keagamaan. Seperti di Masjid al Hidayah Papringan. Mereka ada yang terlibat dalam kepengurusan (ta'mir) masjid. Sebagaimana diungkapkan oleh Ibu Hajar, ketua RW setempat bahwa memang secara institusi kampus UII Demangan Baru tidak pernah menjalin kerja sama dengan masyarakat secara formal, tetapi saat FIAI masih berada di Demangan Baru, para mahasiswa FIAI yang bermukim di Papringan, secara individu banyak juga yang membantu dalam kegiatan keagamaan, seperti terlibat dalam

kepengurusan (ta'mir) masjid. Demikian juga para mahasiswa yang mengambil Kuliah Kerja Nyata (KKN) ekstensi ada juga yang mengambil lokasi pengabdian di sisni dan biasanya mereka membuat program kerja pada aspek sosial keagamaan. Demikian juga para dosen yang bertempat di sekitar juga turut pula terlibat menjadi khotib jumat atau menjadi imam tarawih atau mengisi kultum saat Ramadan (wawancara, 20 Oktober 2014).
Oleh sebab itu keberadaan kampus UII Demangan Baru, sebagai perguruan tinggi Islam bisa mengambil peranan sebagai Agent of Change bagi perubahan sosial keagamaan secara terencana bagi masyarakat sekitar kampus. Terlebih UII seperti dijelaskan di atas, secara institusional menganut dan menjalankan Catur Dharma dalam berbagai unit dan jenjang pendidikan.

Catur Dharma yang dimaksud meliputi Pengajaran, Penelitian, Pengabdian Masyarakat dan Dakwah Islamiyah (statuta UII,pasal 1 ayat 6). Catur Dharma khususnya untuk poin pengabdian masyarakat dan da'wah islamiyah ini menjadi hal yang harus diwujudkan tidak hanya pada level pusat, tetapi juga tercermin dan mewujud pada semua jenis dan level serta unit pendidikan yang ada di bawah naungan UII termasuk didalamnya fakultas, pusat-pusat studi, hingga unit-unit usaha yang dimiliki UII yang ada di kampus Demangan Baru.

Dalam teori interaksi disebutkan, bahwa suatu interaksi sosial akan terjadi apabila memenuhi dua syarat yaitu: (1) adanya kontak sosial; (2) adanya komunikasi. Teori ini jika dikaitkan dengan temuan-temuan data di lapangan, maka menunjukkan bahwa keberadaan kampus UII Demangan Baru belum memiliki andil atau berkontribusi terhadap terjadinya perubahan prilaku keberagamaan masyarakat sekitar karena institusi ini dengan masyarakat sekitar tidak melakukan interelasi dan interaksi antara keduanya.

\section{ANALISIS HASIL PENELITIAN}

Berdasarkan data dan hasil wawancara yang dilakukan terhadap responden, dan berbagai penjelasan di atas, menegaskan bahwa antara pihak Kampus UII Demangan 
Baru dengan masyarakat sekitarnya belum pernah melakukan interaksi untuk melibatkan masyarakat dalam berbagai program kampus ataupun sebaliknya. Hal ini terjadi baik itu pada fakultas (FIAI), termasuk Program Pascasarjana FIAI UII, pusat-pusat studi atau pun unit-unit usaha yang pernah/ sedang menempati kampus Demangan Baru tersebut. Hal ini mengindikasikan kampus Demangan Baru lemah dalam membangun relasi sosial dengan masyarakat sekitar. Sekaligus pihak kampus UII Demangan Baru abai terhadap tanggungjawab membangun kebersamaan sosial terhadap masyarakat sekitar kampus.

Keberadaan kampus, seperti dikemukakan di atas, layaknya berada di pulau yang tentram nyaman di tengah-tengah lautan samudera yang bergolak hebat. Dan dalam pulau yang tentram dan nyaman tersebut duduklah para sarjana, ahli-ahli agama dan segelintir mahasiswa yang sedang belajar. Dan kampus yang dianalogkan tersebut tidak lain adalah kampus Demangan Baru dengan segenap sivitas akademikanya.

Terjadinya jarak antara das sollen (kondisi ideal) dan das sein (kondisi senyatanya) dalam pandangan Yusdani, mantan Kabid akademik MSI UII (1998-2000), dikarenakan pihak kampus terkait selama ini hanya berkutat memikirkan dan mendiskuiskan permasalahan internal kampus seperti pengembangan kampus dengan segenap aktivitas rutinnya; membenahi kurikulum, mencari mahasiswa dan hal-hal terkait pengembangan kampus lainnya. Padahal jika mengacu pada statuta UII kewajiban menjalankan Catur Dharma merupakan tugas pada semua jenis dan jenjang pendidikan.

Oleh karena itu, segenap civitas akademiknya seharusnya mengacu pada visi besar tersebut. Jika pada tingkat universitas pengabdian dan da'wah diwujudkan melalui lembaga pengabdian masyarakat dan DPPAI maka pada level fakultas seharusnya kewajiban menjalankan pengabdian dan dakwah islamiyah juga melekat pada semua jenis dan jenjang pendidikan di bawahnya. (wawancara, 15 Oktober 2014). Pengabdian dan da'wah islamiyah yang harus dijalankan oleh masing-masing jenjang tentunya disesuaikam dengan bidang dan disiplin masing-masing fakultas. Terkait hal ini Yusdani menjelaskan lebih lanjut "(wawancara, 15 Oktober 2014) bahwa kesibukan sivitas akademika terhadap masalah internal kampus, yang lebih tertumpu pada proses pengelolaan belajar mengajar ketimbang kegiatan penelitian dan pengabdian masyarakat, sebagai penyebab absennya atau setidaknya kurang optimalnya kampus Demangan Baru mejalankan da'wah islamiyah di masyarakat sekitar. Dalam hbungan ini, menarik menyimak pandangan Mahfud MD terkait hal tersebut. Dalam pandangannya, UII belum berhasil mencetak sarjana dalam arti yang diinginkan UII seperti diidealkan. Dan belum berhasil pula membangun pola hubungan sivitas akademika yang betul-betul islami. Jika dilihat dari profil alumni yang sudah dihasilkan, UII ternyata belum mampu membebaskan diri dari pola pengembangan ilmu yang dikotomis. Artinya masih sulit menghapus perbedaan fakultas umum dan fakultas agama. Alumnus dari fakultas-fakultas "umum" (ekonomi, hukum, tehnik dan lainlain) belum menunjukkan ke khasannya sebagai produk Perguruan Tinggi Islam. Di sisi lain alumnus fakultas syariah dan tarbiyah (baca; FIAI) tetap saja mengesankan sarjana 
ilmu agama dalam pengertiannya yang sempit.

Ditambahkan Mahfud, bahkan UII sendiri belum berhasil menanamkan sendisendi yang paling mendasar dalam dinul Islam bagi para mahasiswanya. Bukankah tidak sedikit mahasiswa UII yang masuk dengan islam KTP dan keluar dalam keadaan yang sama? Meminjam istilah Syafii Ma'arif Islam masih menjadi tamu di UII. Selain itu pola relasi antar warga sivitas akademika di UII kerap kali menunjukkan gejala yang keras, jauh menunjukkan wajah islam yang sejuk, damai dan anggun. Tentu saja hal ini merupakan akses dari keadaan umum yang tidak kondusif. Artinya jika pandangan Mahfud MD diamini, problem relasi keagamaan di internal UII, justru yang mendesak untuk diselesaikan terlebih dahulu. Hal itu berarti upaya menjalankan da'wah islamiyah di tengah masyarakat sesuai dengan apa yang diamanatkan dalam Catur Dharma tentunya masih jauh dari harapan.

Berdasarkan temuan atau hasil penelitian, Nampak jelas harapan masyarakat di sekitar kampus UII Demangan Baru ataupun kampus yang berada di sekitar jalan Demangan Baru seperti Atmajaya dan Sanata Dharma juga tidak keluar dari dua hal di atas. Bahwa keberadaan kampus diharapkan bisa memperbaiki ekonomi atau memajukan masyarakat sekitarnya. Dan kedua bagaimana keberadaan kampus secara sosial dan keagamaan bisa mewarnai masyarakat dalam pengertian positif. Dalam aspek ekonomi misalnya, seperti pengakuan bapak Sarwono dan ibu Sunarti sebagaimana tersebut di atas.

Komitmen lembaga pendidikan khususnya Perguruan Tinggi Islam dalam menyelesaikan berbagai problem sosial dan moral masyarakat melalui sentuhan program- program yang terencana tentu sesuatu yang diharapkan masyarakat. Seharusnya memang demikian relasi yang terbangun antara keduanya. Kampus tidak bisa lagi mendudukkan diri mereka di atas menara gading yang sangat tinggi. Sudah tidak jamananya lagi dunia perguruan tinggi steril dan mengambil jarak dengan masyakatakatnya . karena di tengah mayarakatlah kehidupan real dengan segenap persoalannya terjadi. Oleh karena itu, relasi yang hendaknya dibangun adalah dunia kampus harus mampu menempatkan diri sebagai agent of change dan turut terlibat dalam penyelesaian berbagai persoalan masyarakat.

Gerakan dakwah Islamiyah berbasis pendekatan ekonomi tampaknya cukup realistis dan strategis untuk dijalankan dalam rangka mewujudkan kampus UII Demangan Baru yang benar-benar hadir di tengah masyarakat. Usulan di atas nampaknya patut dipertimbangkan oleh pihak kampus. Melalui pendekatan ekonomi diharapkan muncul antusiaisme warga untuk terlibat dalam setiap program yang ditawarkan. Jika sudah demikian ,maka penanaman nilai-nilai agama akan mudah dilakukan.

\section{KESIMPULAN}

Sebagai penutup dari keseluruhan deskripsi, analisis dan diskusi yang dikemukakan dalam uraian terdahulu dalam penelitian ini, dapat dikemuakakan kesimpulan-kesimpulan sebagai berikut:

1. Bahwa keberagamaan masyarakat di lingkungan Kampus UII Demangan Baru lebih mengedepankan sikap toleransi. Akan tetapi sikap dan potensi ini, oleh pihak Kampus tidak pernah dilihat sebagai peluang untuk dilakukan berbagai upaya 
penguatan misalnya melalui program dharma ketiga dan keempat (pengabdian dan dakwah Islamiyah) yang berorientasi pada menyantuni warga di lingkungan kampus. Pihak kampus selama ini justru lebih berorientasi pada kesibukan domestiknya memikirkan dan mendiskusikan pengembangan kampus dengan segenap aktivitas rutinnya; proses perkuliahan, membenahi kurikulum, meningkatkan jumlah mahasiswa. dan hal-hal terkait pengembangan kampus lainnya sehingga tidak responsif dalam menjalankan pengabdian masyarakat sebagaimana dimanatkan dalam Catur Dharma UII.

2. Relasi antara pihak kampus UII Demangan Baru dengan berbagai unitnya dan masyarakat di lingkungannya, belum menunjukkan sebagai partner kerjasama terencana dan terprogram secara baik untuk saling mendukung dan bekerjasama antara keduanya. Dengan demikian, aktualisasi dharma ketiga dan keempat (pengabdian masyarakat dan dakwah Islamiyah) UII yang dilakukan oleh unitunit Kampus UII Demangan Baru belum berkontribusi terhadap terjadinya perubahan prilaku keberagamaan masyarakat di lingkungannya.

\section{CATATAN AKHIR}

1 Artikel ini merupakan hasil penelitian institusi PPS FIAI UII pada tahun 2014 yang didanai oleh PPS FIAI UII.

\section{DAFTAR PUSTAKA}

Arifin, Saru dan Irwan Nuryana Kurniawan. 2005. "Kampus Terpadu di Mata Masyarakat Sekitar", dalam UII dalam Cita dan Fakta Bunga Rampai Penelitian Institusi. Yogyakarta: Pusat Penelitian Sosial LPM UIl, hlm 107115.

Darmaji dan M.Idrus. 2005. "Dakwah UII di Masyarakat Sekitar Kampus Terpadu", dalam UII dalam Cita dan Fakta Bunga Rampai Penelitian Institusi. Yogyakarta:
Pusat Penelitian Sosial LPM UII, hlm.117-140.

Kuntowijoyo .1997. Identitas Politik Umat Islam. Bandung: Mizan.

Kuntowijoyo.2001. Muslim Tanpa Masjid. Bandung: Mizan. Mahfud, Moh. 1995. "Kendala-Kendala Pendidikan Islami Di UII", dalam Buku Setengah Abad UII: Sejarah Perkembangan Universitas Islam Indonesia ,Yogyakarta: Ull Press.

Makmun, Abin Syamsudin, 1996. Psikologi Kependidikan(Prenagkat sistem Pengajaran Modul) , Bandung: PT Remaja Rosdakarya.

Martono, Nanang. 2011. Sosiologi Perubahan Sosial: Perspektif Klasik, Modern, Posmodern dan Poskolonial. Jakarta : Rajawali Pers.

Masdar, Umarudin. 2001, Agama Orang Biasa, Jogjakarta: LKiS

Miles, Matthew B. \& Huberman, A. Michael. 1992. Analisis Data Kualitatif, Buku Sumber tentang Metode-metode Baru, Jakarta: UI Press.

Padil, Moh dan Supriyanto, Triyo. 2007, Sosiologi Pendidikan, Yogyakarta: UIN-Malang Press,

"Peran Dakwah Perguruan Tinggi Islam Perlu Dikembangkan" dikutip dari http://fahum.umsu.ac.id/ index.php?option=com_content\&view=article\&id=99:perandakwah-perguruan-tinggi-islam-perludikembangkan\&catid=30:liputan\&ltemid=50 accessed 15 Juli 2014.

Oodir, Zuly, 2011. Sosiologi Agama: Esai-Esai Agama di Ruang Publik,Yogyakarta: Pustaka Pelajar

Robertson, Roland, 1993. Agama dalam Analisa dan Interpretasi sosiologi, terj. Ahmad Fedyani, Saifuddin. Jakarta: Rajawali Press.

Suhardjo, Drajat, Fuad Nashori dan Hastuti Saptorini, 2005. "Kemitraan:Solusi Kampus Ramah Lingkungan", dalam UII dalam Cita dan Fakta Bunga Rampai Penelitian Institusi. Yogyakarta: Pusat Penelitian Sosial LPM UII, hlm.157-165.

Supardi, dkk, 1994. Setengah Abad UIl; Sejarah Perkembangan UII 8 Juli 1945- 10 Januari 1994, Yogyakarta: UII Press,

Tim Peneliti LPPAI UII. 2006."Faktor Faktor Yang Berkaitan Dengan Motivasi Berbusana Muslimah Mahasiswi UII", dalam Jurnal Fenomena LP. UII Vol.4. No.1 Maret 2006.

Tim Penulis UII.1994. Setengah Abad UII: Sejarah Perkembangan Universitas Islam Indonesia. Yogyakarta: UII.

Tim Penyusun. 2002. Sejarah dan Dinamika Universitas Islam Indonesia. Yogyakarta: Badan Wakaf UII Yogyakarta.

Wahid, Fathul, Gerakan Membina Kampus Islami dikutip dari http://fathulwahid.staff.uii.ac.id/2006/10/07/ gema-kami-gerakan-membina-kampus-islami/ didownload 2 April 2013.

Wahid. Fathul.2006."Gerakan Membina Kampus Islami," dalam Bulletin al-Islamiyah. Yogyakarta: DPPAI UII. 
Wahid, Marzuki, "Wacana PTAl dalam Perkembangan Pemikiran Islam: Mempertanyakan Kontribusi" dikutip dari $8 \& p=$ uang+dalam+Islam\&fr=yfp-t$01 \& f p \_i p=\mid D \& u=w w w$. ditpertais.net/jurnal/ vol62003e.asp\& $\mathrm{w}=$ uang+dalam+islam\&d=N9vlNedmPbY Eicp=18.intl=us accessed 14 Juli 2014.

Wijdan Aden, dkk. 2007. Pemikiran dan Peradaban Islam. Yogyakarta: Safiria Insania Press and Pusat Studi Islam Universitas Islam Indonesia (PSI UII).

Wijdan, Aden, M. Latif Fauzi. 2011. Nalar Islam Universitas Islam Indonesia. Yogyakarta: Direktorat Penelitian \& Pengabdian Masyarakat Universitas Islam Indoneisa (DPPM UII).

Wijdan, Aden, M. Roem Syibly. 2010. Qanun; Journal of Islamic Law. Volume I, Number 1, February 2010. Yogyakarta: Directorate Programme of Islamic Law. Faculty of Islamic Studies. Islamic University of Indonesia.

Yusdani, Nyarwi, M. Roem Syibly. 2011. Tipologi Wacana Keislaman Yogyakarta. Yogyakarta: Pusat Studi Islam Universitas Islam Indonesia (PSI UII).

\section{Narasumber:}

Bapak Heri, warga Demangan Baru No. 29 yang sehari-hari usaha foto copy dan kebutuhan alat tulis (ATK) (wawancara 10 Oktober 2014)

Bapak Ibu Hajar, Ketua RW setempat (wawancara, 20 Oktober 2014).

Bapak Sarwono pemilik warung makan yang berada tepat di depan Kampus UII Demangan (wawancara 10 Oktober 2014)

Bapak Yusdani, mantan Kabid Akademik MSI UII (19982000) (wawancara, 15 Oktober 2014),

Ibu Sunarti, warga Demangan Baru yang sehari-hari berjualan di sekitar Kampus UII Demangan Baru, (wawancara, 10 Oktober 2014)

Imam Muharor, Tokoh Agama dan Tokoh Masyarakat di Padukuhan Papringan (wawancara, 16 Oktober 2014).

Nur Hamid Kepala Dukuh Papringan (wawancara 15 Oktober 2014). 